\title{
Cyanobacterial occurrence and detection of microcystin by planar chromatography in surface water of Billings and Guarapiranga Reservoirs, SP, Brazil
}

\author{
LUCIANA R. DE CARVALHO ${ }^{1,2}$, CÉLIA L. SANT'ANNA ${ }^{1}$, MARCINA C.P. GEMELGO ${ }^{1}$ and \\ MARIA TERESA DE P. AZEVEDO ${ }^{1}$
}

(received: March 31, 2005; accepted: February 15, 2007)

\begin{abstract}
Cyanobacterial occurrence and detection of microcystins by planar chromatography in surface water of Billings and Guarapiranga Reservoirs, SP, Brazil). Billings and Guarapiranga Reservoirs were deeply affected by environmental disturbances, which more evident consequence are the cyanobacterial blooms. Microcystins are the most common cyanotoxin in freshwaters and more than 70 types are known. Different methods for microcystins analysis in water can be used, among which ELISA and HPLC are the most frequently employed. However, less sophisticated and more economic methods can also be used. This is the case of planar chromatography (thin-layer chromatography) method previously used in cyanotoxins purification but gradually replaced by others. Posterior optimization of the microcystin chromatography conditions and because of its simplicity, rapidity, efficiency and low cost, this method is again considered an option for the analysis of microcystins and nodularins. Considering the importance of Billings and Guarapiranga Reservoirs for drinking water supplies and the few scientific data about cyanobacteria and cyanotoxins in these water bodies, the aims of this work are to analyze the biodiversity of cyanobacteria in the Billings and Guarapiranga Reservoirs and the detection of dissolved microcystins in the water. It was possible to identify 17 species of cyanobacteria, 9 of them being potentially toxic. In Billings Reservoir Microcystis aeruginosa (Kützing) Kützing and Cylindrospermopsis raciborskii (Woloszynska) Seenayya \& Subba Raju are the most common species, while in Guarapiranga Reservoir only M. aeruginosa was considered as a common species. Microcystins were detected in all Billings Reservoir samples and in only one sample from Guarapiranga Reservoir.
\end{abstract}

Key words - cyanobacteria, drinking water, microcystins, planar chromatography, reservoirs

RESUMO - (Ocorrência de cianobactérias e detecção por cromatografia planar de microcistinas dissolvidas nas águas superficiais das represas Billings e de Guarapiranga, SP, Brasil). As represas Billings e Guarapiranga foram profundamente afetadas por fatores ambientais cuja conseqüência mais evidente são as florações de cianobactérias. As microcistinas formam a classe de cianotoxinas mais freqüente em água doce e são comumente analisadas por ELISA ou CLAE. No entanto, processos menos sofisticados e mais econômicos também podem ser usados. Este é o caso da cromatografia planar (cromatografia em camada delgada), método anteriormente usado em trabalhos de purificação de cianotoxinas, mas que foi gradualmente substituído por outros. Assim, considerando a importância das represas Billings e Guarapiranga para o abastecimento público e a carência de informações científicas sobre as cianobactérias e as cianotoxinas que nelas ocorrem, nossos objetivos foram o estudo da composição desses organismos e a detecção de microcistina dissolvida na água. Foi possível identificar 19 espécies de cianobactérias, das quais 9 são consideradas potencialmente tóxicas. Microcystis aeruginosa (Kützing) Kützing e Cylindrospermopsis raciborskii (Woloszynska) Seenayya \& Subba Raju são as espécies mais comuns no Reservatório Billings e, na Guarapiranga, apenas M. aeruginosa foi considerada como espécie de ocorrência comum. Microcistina-LR foi detectada em todas as amostras da Represa Billings e em somente uma amostra da Represa Guarapiranga.

Palavras-chave - água de abastecimento, cianobactérias, cromatografia planar, microcistinas, reservatórios

\section{Introduction}

The twentieth century was marked by heavy damages caused to the environment and water eutrophication is one of the worst consequences. The eutrophication process is more intense in water bodies

1. Instituto de Botânica, Seção de Ficologia, Caixa Postal 3005, 01061-970 São Paulo, SP, Brazil.

2. Corresponding author: lretz@uol.com.br near great urban centers as the Metropolitan Region of São Paulo City where over 15 million people live and hundreds of industries are located (Cetesb 1998).

For many decades the water bodies in this region have been intensely impacted by domestic and industrial waste input, deforestation, soil erosion and irregular land use in the surrounding areas (Sendacz \& Kubo 1999). Billings and Guarapiranga Reservoirs, that make part of this complex system, were also deeply affected by environmental impacts. 
Few scientific articles on phytoplankton in Billings and Guarapiranga Reservoirs describe the transformations occurred in these water bodies, including the development of cyanobacterial blooms.

In the beginning of the eighties, Xavier (1981) studied the phytoplanktonic community in Billings Reservoir and did not report the presence of cyanobacterial blooms. At the end of the nineties, Souza et al. (1998) analyzed the water quality of Billings for one year, and observed that Cylindrospermopsis raciborskii (Wolosz.) Seenayya \& Subba Raju (Cyanobacteria) was the dominant species. Carvalho (2003) studied the phytoplanktonic community in Billings and its use as a tool for monitoring water quality and found out that cyanobacteria were the dominant group throughout the studied period.

Concerning Guarapiranga Reservoir, Zagatto et al. (1996) evaluated water quality based on ecological and toxicological aspects and detected toxic blooms of cyanobacteria which poisonous effects were confirmed by mice testing. Beyruth (1996) studied the Guarapiranga phytoplanktonic community and also detected blooms of cyanobacteria. The direct correlation between these blooms and the nutrient input was demonstrated.

Sant'Anna \& Azevedo (2000) studied the potentially toxic Brazilian cyanobacteria from different reservoirs, including Billings and Guarapiranga. The authors showed that Microcystis, Anabaena, Aphanizomenon, Cylindrospermopsis, Raphidiopsis and Planktothrix are the most widely distributed genera in Brazilian reservoirs. The blooms of these genera are toxic in more than 65\% of occurrences (Costa \& Azevedo 1994).

Regarding cyanotoxins, microcystin is the most common toxin in freshwaters and around 70 different types are known (Spoof et al. 2003). It is possible to use several methods for the microcystin analysis but ELISA and HPLC are the most frequently used. However, less sophisticated and less expensive methods can also be employed as discussed in the present paper. This is the case of planar chromatography, or the thinlayer chromatography, a method previously used in hepatotoxins purification (Poon et al. 1987, Harada et al. 1888a, b) but gradually replaced by others. Based on its simplicity, rapidity, efficiency and low cost, the thin-layer chromatographyc method has been improved (Ojanperä et al. 1995, Pelander et al. 1996, 1997, 1998, 2000) and it is considered a good procedure to detect microcystins and nodularins. The use of Amberlite XAD-2 for clean-up and solid-phase extraction during the microcystin purification process is also described (Pietrzy 1989, Lingeman \& Tjandem 1990).
Clean-up and solid-phase extraction (SPE) are common steps in the cyanobacterial and water sample preparation and are usually performed with the hydrophobic chemically modified silica $\mathrm{C}_{18}$. In this process, the analytes are adsorbed onto the hydrophobic material by means of van der Waals interactions and to some extent by hydrophobic bonding or dipole-dipole interactions (Lingeman \& Tjaden 1990). The styrene divinylbenzene copolymer XAD-2 is an hydrophobic sorbent too, that is applied for clean-up and concentration of protein-rich matrix (Lingeman \& Tjaden 1990). The suitability of the use of XAD-2 in qualitative analyses of microcystin-LR was evaluated.

The aims of this work are to analyze the biodiversity of cyanobacteria in the Billings and Guarapiranga Reservoirs and to detect the dissolved microcystin in the water.

\section{Material and methods}

Eighteen 20-liter samples (9 from each reservoir) were collected monthly from the surface of Billings and Guarapiranga Reservoirs, since December/2000 till August/2001. Table 1 presents the main characteristics of these reservoirs.

Biological studies - From each sample, $100 \mathrm{~mL}$ of water was preserved in formaldehyde for taxonomic studies under light microscope; other similar aliquot was kept alive for isolating and culture of cyanobacteria strains; the remaining sample was used for the microcystin analysis.

The culture conditions were: BG-11 and/or AMS-1 media, temperature $22^{\circ} \mathrm{C} \pm 1{ }^{\circ} \mathrm{C}$, irradiances $15-20 \mu$ mol photons $\mathrm{m}^{-2} \mathrm{~s}^{-1}$ and 10-14 hours light-dark cycle (Azevedo \& Sant'Anna 2003). All culture strains studied, including the strain SPC 686 used for the microcystin purification, belong to the "Instituto de Botânica” Algae Culture Collection (SPC) - SMA.

Table 1. Main characteristics of Billings and Guarapiranga Reservoirs, according to Beyruth (2000) and Carvalho (2003).

\begin{tabular}{lcc}
\hline & \multicolumn{2}{c}{ Reservoir } \\
\cline { 2 - 3 } & Billings & Guarapiranga \\
\hline Location & $23^{\circ} 47^{\prime} \mathrm{S}$ and & $23^{\circ} 43^{\prime} \mathrm{S}$ and \\
Mean depth $(\mathrm{m})$ & $46^{\circ} 40^{\prime} \mathrm{W}$ & $46^{\circ} 32^{\prime} \mathrm{W}$ \\
Area $\left(\mathrm{km}^{2}\right)$ & 10 & 5.7 \\
Transparency $(\mathrm{m})$ & 127 & 33.981 \\
Retention time $($ days $)$ & 1.20 & 2.00 \\
Conductivity $\left(\mu \mathrm{S} \mathrm{cm}^{-1}\right)$ & 538 & 185 \\
Chlorophyll a $\left(\mu \mathrm{g} \mathrm{L}^{-1}\right)$ & 41.20 & 168.70 \\
\end{tabular}


The classification system of Anagnostidis \& Komárek (1988) and Komárek \& Anagnostidis $(1989,1999)$ was adopted for cyanobacteria identification.

Chemical essays - Study on material from culture and on water samples using Amberlite XAD-2 (Supelco) for microcystins solid-phase extraction.

Culture - About $780 \mathrm{mg}$ of lyophilized cells of the Microcystis panniformis SPC 686 strain were extracted ( $3 \mathrm{x})$ with $\mathrm{MeOH} /$ $\mathrm{H}_{2} \mathrm{O}(75: 25 \mathrm{v} / \mathrm{v})$ by exposure to ultrasound ( 4 x $\left.30 \mathrm{sec} ; 50 \mathrm{~W}\right)$ and centrifugation at $1045 \mathrm{x} \mathrm{g}$ for $60 \mathrm{~min}$. (Ramanan et al. 2000). The supernatants were combined and evaporated under reduced pressure to remove the organic solvent; the aqueous residue was lyophilized (dried weight $=0.175 \mathrm{~g}$ ), dissolved again in deionized water and applied to an Amberlite XAD-2 column (Supelco, $10 \times 2.5 \mathrm{~cm}$ ). The eluting solvents were $\mathrm{H}_{2} \mathrm{O}(20 \mathrm{~mL}), \mathrm{MeOH} / \mathrm{H}_{2} \mathrm{O}(20: 80, \mathrm{v} / \mathrm{v})(20 \mathrm{~mL})$ and $\mathrm{MeOH}(30$ $\mathrm{mL}$ ) (Pietrzyk 1989, Lingeman \& Tjandem 1990). These three eluates were taken to dryness $(96.0,9.0$, and $51.4 \mathrm{mg}$, respectively) and suspended again in $1 \mathrm{~mL}$ of $0.9 \%(\mathrm{w} / \mathrm{v})$ $\mathrm{NaCl}$ solution. A small aliquot of each one was applied to silica gel thin-layer chromatography plates that were developed with the solvent systems: $\mathrm{CH}_{3} \mathrm{CO}_{2} \mathrm{C}_{2} \mathrm{H}_{5}$ / $\left(\mathrm{CH}_{3}\right)_{2} \mathrm{CHOH} / \mathrm{H}_{2} \mathrm{O}\left(9: 6: 5, \mathrm{v} / \mathrm{v} / \mathrm{v}\right.$, upper layer) and $\mathrm{CHCl}_{3} /$ $\mathrm{MeOH} / \mathrm{H}_{2} \mathrm{O}(65: 35: 10, \mathrm{v} / \mathrm{v} / \mathrm{v}$, lower layer) and were used in all chromatographic runs performed. The visualization of microcystin spots of the samples and of the purified microcistin was done with short wavelength UV light, with iodine vapors and by derivatization with TMB $(3,3,5$, 5-tetramethylbenzidin) (Harada et al. 1988b, Pelander et al. 2000). The toxicity testing was carried out with an i.p. injection into Swiss-Webster male mice (20-25 g body weight). Two animals were used for the first eluate, one for the second and two for the third. The time of death was recorded and the remaining mice, including the control animal, were observed for 24 hours.

Water sample - each water sample (10 L) from Billings and Guarapiranga reservoirs was filtered through a glass-fiber filter (GF/C Whatman) and applied directly to an Amberlite XAD-2 (Supelco) vacuum column $(10 \times 2.5 \mathrm{~cm})$ before elution decreased, thereby providing an indication of maximum sample load; the loaded column was washed with water (30 mL) followed by $\mathrm{H}_{2} \mathrm{O} / \mathrm{MeOH}(80: 20$, v/v) $(30 \mathrm{~mL})$ and subsequently by methanol $100 \%(30 \mathrm{~mL})$. The column was regenerated (Pietrzyk 1989, Lingeman \& Tjandem 1990) and the procedure was repeated for the whole sample. The methanolic eluates were combined, evaporated under reduced pressure and then the residues were reconstituted with methanol $(0.5 \mathrm{~mL})$ and applied to silica gel plates $(20 \times 20 \mathrm{~cm}$, $0.25 \mathrm{~mm}$, Kieselgel $60 \mathrm{GF}_{254}$, E. Merck) that were developed with the same solvent systems as described by Harada et al. (1988b). The microcystin spots of the samples and purified microcystin were visualized with short-wavelength UV, iodine vapor and by derivatization with TMB (3, 3, 5, 5-tetramethylbenzidin) (Harada et al. 1988b, Pelander et al. 2000).
Analysis of microcystins in water samples from the reservoirs using silica gel planar chromatography - For evaluating toxin concentration, ten-liter water samples were filtered through a glass-fiber filter GF/C Whatman and applied directly to an Amberlite XAD-2 vacuum column $(10 \times 2.5 \mathrm{~cm})$ and eluted as previously described for water samples. The combined eluate in $100 \%$ methanol was evaporated under reduced pressure and then the residue was suspended again in $0.5 \mathrm{~mL}$ of methanol. This suspension was subjected to a silica gel column (E. Merck, Kieselgel 60, 230-400 mesh, $10 \times 2.5 \mathrm{~cm}$ ) preconditioned with $\mathrm{MeOH}-100 \%$. After washing with $20 \mathrm{~mL}$ of $\mathrm{MeOH} 100 \%$, microcystins were eluted with $25 \mathrm{~mL}$ of the solvent system $\mathrm{H}_{2} \mathrm{O} / \mathrm{TFA} / \mathrm{MeOH}-(10: 0.1: 89.9$, v/v/v) (Tsuji et al. 1994, Harada 1996). This eluate containing microcystins was evaporated to dryness.

Planar Chromatography - The dried microcystin fraction was dissolved in a small volume of methanol and applied to silica gel plates (E.Merck, Kieselgel $60 \mathrm{GF}_{254}, 20 \times 20 \mathrm{~cm}, 0.25 \mathrm{~mm}$ ) according to Harada et al. (1988b). The positions of the microcystin spots in the plates were evaluated (Pelander $e t$ al. 2000). The microcystin-LR was isolated from a strain of Microcystis panniformis SPC 686 ("Coleção de Culturas de Algas e Cianobactérias do Instituto de Botânica"), purified and recognized by its mass spectrum (figure 1). ESI-MS analyses were carried out on a Q-TOF Micro (Micromass Ltd, Manchester, UK) mass spectrometer fitted with an electrospray ion source, operating in positive ion mode. The capillary voltage was $3-3.5 \mathrm{kV}$ and sample cone voltages were 30-40V.

Hepatotoxic water bloom in Guarapiranga reservoir Cyanobacterial cells were obtained from a surface bloom collected in August 2001. The toxin extracted from freezedried cells in $0.9 \%(\mathrm{w} / \mathrm{v})$ with $\mathrm{NaCl}$ solution $\left(25.5 \mathrm{mg}\right.$ cells $\left.\mathrm{mL}^{-1}\right)$ by repeated bath ultrasonication $(4 \times 30 \mathrm{sec}, 50 \mathrm{~W})$. The extract was centrifuged ( 1045 x $g 60 \mathrm{~min}$ ) and analyzed in silica gel thin-layer chromatography, as previously described. The obtained supernatant was i.p. injected in seven SwissWebster male mice weighing 20 to $25 \mathrm{~g}$. The doses ranged from 869.05 to $346.47 \mathrm{mg}$ dry weight cyanobacteria $\mathrm{kg}^{-1} \mathrm{~b}$.w. and the signs of poisoning and survival times were recorded. Postmortem necropsies were carried out.

Derivatization reaction with TMB - The developed plate was exposed to chlorine gas for 20 minutes in a glass tank. The chlorine gas was generated by mixing equal volumes of $10 \%$ $\mathrm{HCl}$ and $5 \% \mathrm{KMn} \mathrm{O}_{4}$. After exposure, the plate was sprayed with TMB (3, 3, 5, 5-tetramethylbenzidin) solution that was prepared by dissolving $8 \mathrm{mg}$ of TMB in 1.5 glacial $\mathrm{CH}_{3} \mathrm{COOH}$ and $25 \mathrm{~mL}$ of $\mathrm{H}_{2} \mathrm{O}$ and $50 \mathrm{mg}$ of $\mathrm{KI}$ were added (Pelander $e t \mathrm{al}$. 2000). All chemicals were analytical-reagent grade.

\section{Results and Discussion}

Cyanobacterial biodiversity - The results showed that cyanobacterial biodiversity as well as the number of potentially toxic species are greater in Billings than in 


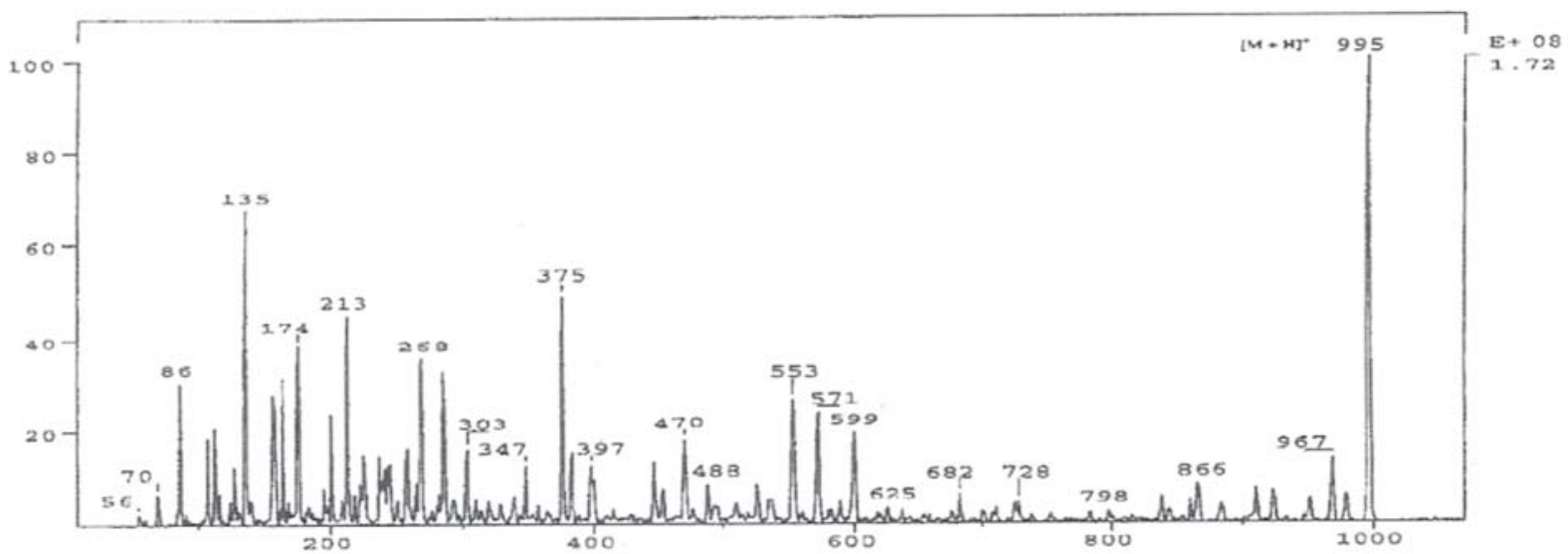

Figure 1. ESI-Q-TOF/MS spectrum of microcystin-LR. Molecular ion $[\mathrm{M}+\mathrm{H}]^{+}$and characteristic fragmentation pattern can be observed.

Guarapiranga Reservoir (table 2). A first consequence is the strong probability to detect cyanotoxins in Billings water considering that $67 \%$ of the species collected in this reservoir are potentially toxic. In relation to the number of cyanobacteria species, in the Guarapiranga reservoir this possibility decreases to $50 \%$. Furthermore, the cyanobacterial abundance is always high in Billings water and cyanobacterial blooms were always observed. The microcystin analyses confirm these results: presence of dissolved microcystin in Billings Reservoir during the whole studied period (table 3). On the other hand, in Guarapiranga reservoir the presence of dissolved microcystin was detected only once, in the sample containing Microcystis in 01/August/2001 (table 4).

Blooms of Microcystis species were found in

Table 2. Cyanobacteria species found in samples of Billings and Guarapiranga Reservoirs. * Potentially toxic species, according to Chorus \& Bartram (1999).

\begin{tabular}{|c|c|c|}
\hline Species & Billings & Guarapiranga \\
\hline \multicolumn{3}{|l|}{ CHROOCOCCALES } \\
\hline Aphanocapsa delicatissima West \& G. S. West & + & + \\
\hline Chroococcus sp. & + & + \\
\hline Microcystis aeruginosa* (Kützing) Kützing & + & + \\
\hline M. botrys* Teiling & + & \\
\hline M. novacekii* (Komárek) Compère & + & \\
\hline M. panniformis* Komárek & + & + \\
\hline M. protocystis $*$ Crow & + & \\
\hline M. wesenbergii* (Komárek) Komárek & + & \\
\hline \multicolumn{3}{|l|}{ OSCILLATORIALES } \\
\hline Geitlerinema unigranulatum Komárek \& M. T. P. Azevedo & + & + \\
\hline Limnothrix planctonica (Woloszynska) Meffert & + & \\
\hline Phormidium sp. & & + \\
\hline Planktothrix agardhii* (Gomont) Anagnostidis \& Komárek & + & + \\
\hline Pseudanabaena galeata Böcher & + & \\
\hline P. mucicola (Naumann \& Huber-Pestalozzi) Schwabe & + & + \\
\hline Romeria gracilis (Koczwara) Koczwara ex Geitler & + & \\
\hline \multicolumn{3}{|l|}{ NOSTOCALES } \\
\hline Anabaena planctonica* Brunnthaler & & + \\
\hline Cylindrospermopsis raciborskii (Woloszynska) Seenayya \& Subba Raju & + & + \\
\hline Total & 15 & 10 \\
\hline
\end{tabular}


Table 3. Potentially toxic cyanobacteria isolated from Billings Reservoir and microcystins presence. *Most common species.

\begin{tabular}{|c|c|c|}
\hline Date & Species & Presence of microcystins \\
\hline 20/Dec./2000 & Cylindrospermopsis raciborskii, Microcystis sp., Planktothrix agardhii & + \\
\hline 17/Jan./2001 & $\begin{array}{l}\text { Cylindrospermopsis raciborskii*, Microcystis aeruginosa*, } \\
\text { Planktothrix agardhii }\end{array}$ & + \\
\hline 14/Feb./2001 & Cylindrospermopsis raciborskii*, Microcystis sp. & + \\
\hline 10/Apr./2001 & Cylindrospermopsis raciborskii*, Microcystis panniformis & + \\
\hline 25/Apr./2001 & Cylindrospermopsis raciborskii, Microcystis aeruginosa & + \\
\hline 23/May/2001 & Cylindrospermopsis raciborskii*, Microcystis aeruginosa & + \\
\hline 06/Jun./2001 & Cylindrospermopsis raciborskii, Microcystis aeruginosa, $M$. panniformis & + \\
\hline 04/Jul./2001 & Microcystis aeruginosa* ${ }^{*}, M$. panniformis, $M$. protocystis & + \\
\hline 01/Aug./2001 & $\begin{array}{l}\text { Cylindrospermopsis raciborskii, Microcystis aeruginosa*, M. panniformis*, } \\
\text { M. protocystis, } M . \text { novacekii }\end{array}$ & + \\
\hline
\end{tabular}

Table 4. Potentially toxic cyanobacteria isolated from Guarapiranga Reservoir and microcystins presence. *Most common species.

\begin{tabular}{llc}
\hline Date & Species & Presence of microcystins \\
\hline 20/Dec./2000 & Cylindrospermopsis raciborskii, Microcystis sp., Planktothrix agardhii & - \\
17/Jan./2001 & $\begin{array}{c}\text { Anabaena planctonica, Cylindrospermopsis raciborskii, Microcystis aeruginosa, } \\
\text { Planktothrix agardhii }\end{array}$ & - \\
14/Feb./2001 & Cylindrospermopsis raciborskii, Phormidium sp. & - \\
10/Apr./2001 & Phormidium sp. & - \\
25/Apr./2001 & - & - \\
23/May/2001 & Planktothrix agardhii & - \\
06/Jun./2001 & Cylindrospermopsis raciborskii, Microcystis sp. & - \\
04/Jul./2001 & Microcystis panniformis & - \\
01/Aug./2001 & Anabaena planctonica, Cylindrospermopsis raciborskii, Microcystis aeruginosa $*$, & + \\
& M. panniformis, M. protocystis, Planktothrix agardhii & \\
\hline
\end{tabular}

Billings Reservoir throughout the studied period, as also previously reported by Carvalho (2003). Different results were obtained for Guarapiranga Reservoir where Microcystis species did not form blooms. The only exception was the $M$. aeruginosa bloom formed in August 2001, probably favored by the low level of water during the dry season and high nutrients concentration (Cetesb 2003).

Table 5 shows the Microcystis species associated with oscillatorian cyanobacteria found in the samples with positive results for microcystins, mainly in Billings Reservoir. It is worth mentioning that, except for Planktothrix agardhii, it is still unknown whether the other Oscillatoriales identified are able to produce toxins.

Based on its biodiversity, it is possible that the development of cyanobacteria is much more favored by physical and chemical conditions in Billings than those in Guarapiranga. Our results show clear differences between both reservoirs concerning the biodiversity of cyanobacterial species. However, it is difficult to predict how long this condition will remain because since 2000 the reservoirs have been connected by a channel that carries water from Billings to Guarapiranga (Cetesb 2003). Certainly this fact will change the species composition and density of the phytoplanktonic community of Guarapiranga Reservoir.

Chemical essays - Solid-phase extraction of microcystins from the culture and the water samples using Amberlite XAD-2.

To date, the clean-up and concentration of samples were mostly performed in octadecylsilanized silica $\left(\mathrm{C}_{18}\right)$ (Harada 1996, Meriluoto 1997) but the potential of stationary phases other than $\mathrm{C}_{18}$ has been evaluated for 
Table 5. Cyanobacteria species found in samples with positive results for microcystins. *Microcystins producers species, according to Chorus \& Bartram (1999), **Species kept in culture.

\begin{tabular}{lcc}
\hline Species & \multicolumn{2}{c}{ Reservoirs } \\
\cline { 2 - 3 } & Billings & Guarapiranga \\
\hline CHROOCOCCALES & & \\
Aphanocapsa delicatissima & + & \\
$*$ Microcystis aeruginosa $* *$ & + & + \\
$* M$. botrys** & + & \\
$* M$. novacekii & + & \\
$*$ M. panniformis** & + & + \\
$*$ M. protocystis $* *$ & + & + \\
$*$ M. wesenbergii & + & \\
OSCILLATORIALES & & + \\
Geitlerinema unigranulatum & + & + \\
Limnothrix planctonica & + & + \\
$*$ Planktothrix agardhii** & + & + \\
Pseudanabaena galeata & + & \\
P. mucicola & + & + \\
Romeria gracile & + & \\
\hline
\end{tabular}

these procedures. Therefore, some phases like Oasis ${ }^{\hat{a}}$ HLB (Waters) and immunoaffinity columns were compared to $\mathrm{C}_{18}$ cartridges, with better performances than the latter (Rapala et al. 2002, Aranda-Rodriguez et al. 2003).

In the current work, the sorbent XAD-2 (Pietrzyk 1989), a neutral hydrophobic polymer, was tried as stationary phase for microcystins concentration. After experiments, the concentrating conditions were established for culture and water samples and a solvent elution scheme similar to that preconized by Pietrzyk (1989) was adopted. The solvent series are: deionized water; $\mathrm{MeOH} / \mathrm{H}_{2} \mathrm{O}(20: 80$, v/v) and $\mathrm{MeOH} 100 \%$.

Toxicity testing with fractions from culture of M. panniformis SPC 686: mice tested with aqueous and methanolic-aqueous $(20: 80, \mathrm{v} / \mathrm{v})$ eluates from the Amberlite XAD-2 column did not show any sign of poisoning but methanolic (100\%) fraction caused typical signs of microcystin poisoning (weakness, paralysis, piloerection, diarrhea, pallor of extremities and heavy breathing) and death after an average time of 1hour and 3 minutes.

Planar chromatography with material from culture and water sample: microcystins were detected in the methanolic eluates obtained from the XAD-2 columns, for culture and water sample, using silica gel thin-layer chromatography, under the conditions previously related.
These results appear to offer high potential for concentrating water samples when the purpose is to detect microcystin-LR.

The identity of the toxin from M. panniformis SPC 686 (microcystin-LR) is supported by the molecular ion at $\mathrm{m} / \mathrm{z} 995.6$ and by the characteristic series of ions present in the spectrum (Diehnelt et al. 2005).

Analysis of microcystins from reservoir water samples by planar chromatography (silica gel thin-layer chromatography) - Environmental samples contain a multitude of interfering contaminants. The clean-up process with octadecilsilanized silica is not always sufficient to eliminate the impurities and avoid background interferences in chromatograms (Harada 1996, Pelander et al. 2000). So an additional clean-up process is required and the treatment with silica gel is very effective for this purpose (Harada 1996).

Thin-layer chromatographic methods have been widely employed for the analysis of microcystins and for the isolation and purification of authentic microcystin standards. It is a rapid, simple and inexpensive procedure that effectively enables the detection of these toxins (Poon et al. 1987, Harada et al. 1988b, Meriluoto 1997, Pelander et al. 1998, 2000). The detection limit for the purified microcystins is $1 \mathrm{ng}$. For microcystins in water or culture samples it was found to be $1 \mathrm{mg} \mathrm{L}^{-1}$; this higher limit is due to interference from other substances, in natural samples (Harada et al. 1988b, Meriluoto 1997, Pelander et al. 1998, 2000).

Figures 2-3 and table 5 show the results obtained from qualitative planar chromatographic analysis of water samples from Guarapiranga and Billings Reservoirs. Microcystins were detected in all Billings Reservoir samples and in only one sample from Guarapiranga Reservoir.

Hepatotoxic water bloom occurred in August 2001, in Guarapiranga Reservoir - All animals injected with the toxic extract presented symptoms of poisoning similar to those described for microcystins and died in a time ranging from 50 minutes to two hours and five minutes. Upon autopsy, swollen and blood-engorged livers were observed. These results confirm the toxicity of this bloom.

This study showed a constant incidence of microcystins in Billings Reservoir and a single occurrence (August 2001) in Guarapiranga Reservoir (table 2) and these results are coincident with the biological studies, indicating the toxicity of Microcystis species in both reservoirs. It was also possible to identify 17 species of cyanobacteria, 9 of them considered potentially toxic. Microcystis aeruginosa and 


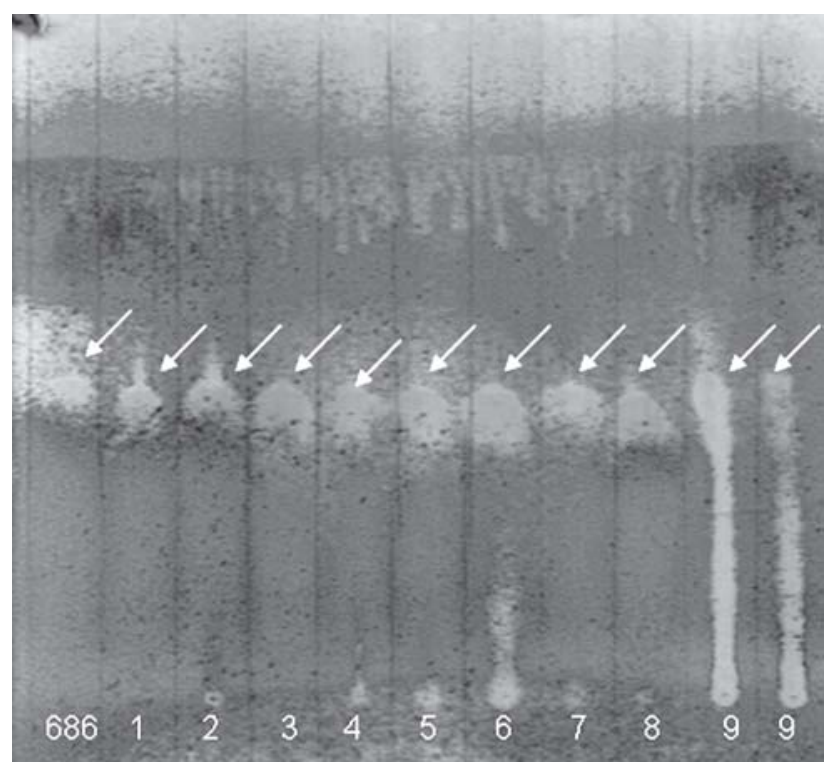

Figure 2. Chromatogram (planar chromatography) of 686 (purified microcystin-LR) and of Billings samples; 1 (20/Dec./2000), 2 (17/Jan./2001), 3 (14/Feb./01), 4 (10/Apr./2001), 5 (25/Apr./2001), 6 (23/May/2001), 7 (06/Jun./2001), 8 (04/Jul./2001) and 9 (01/Aug./2001). Mobile phase: $\mathrm{CHCl}_{3} / \mathrm{MeOH} / \mathrm{H}_{2} \mathrm{O}(65: 35: 10$, v/v/v, lower layer). Detection: TMB (3, 3, 5, 5-tetramethylbenzidin). Arrows indicate the microcystin-LR spots.

Cylindrospermopsis raciborskii were the most common species in Billings Reservoir, while Reservoir only M. aeruginosa was considered a common species in Guarapiranga.

Acknowledgements - This work was supported by Conselho Nacional de Desenvolvimento Científico e Tecnológico (CNPq) and Fundo Estadual de Recursos Hídricos (Fehidro).

\section{References}

ANAGNOSTIDIS, K. \& KOMÁREK, J. 1988. Modern approach to the classification system of Cyanophytes 3 - Oscillatoriales. Algological Studies 50-53:327-472.

ARANDA-RODRIGUEZ, R., KUBWABO, C. \& BENOIT, F.M. 2003. Extraction of 15 microcystins and nodularin using immunoaffinity columns. Toxicon 42:587-599.

AZEVEDO, M.T.P. \& SANT'ANNA, C.L. 2003. Sphaerocavum brasiliense, a new planktic genus and species of Cyanobacteria from reservoirs of São Paulo State, Brazil. Algological Studies 109:79-92.

BEYRUTH, Z. 1996. Comunidade fitoplanctônica da Represa de Guarapiranga: aspectos ecológicos, sanitários e subsídios para reabilitação da qualidade ambiental. Tese de Doutorado, Universidade de São Paulo, São Paulo.

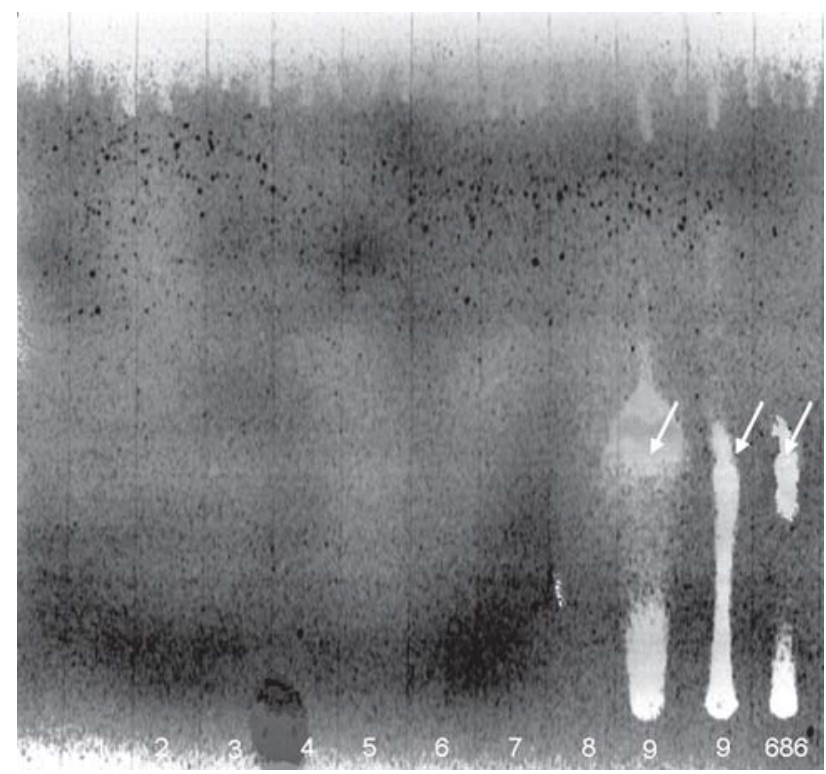

Figure 3. Chromatogram (planar chromatography) of Guarapiranga samples; 1 (20/Dec./00), 2 (17/Jan./01), 3 (14/ Feb./01), 4 (10/Apr./01), 5 (25/Apr./01), 6 (23/May/01), 7 (06/ Jun./01), 8 (04/Jul./01) and 9 (01/Aug./01) and of 686 (purified microcystin-LR). Mobile phase: $\mathrm{CHCl}_{3} / \mathrm{MeOH} / \mathrm{H}_{2} \mathrm{O}$ (65:35:10, v/v/v, lower layer). Detection: TMB (3, 3, 5, 5tetramethylbenzidin). Arrows indicate the microcystin-LR spots.

BEYRUTH, Z. 2000. Periodic disturbances, trophic gradient and phytoplankton characteristics related to cyanobacterial growth in Guarapiranga Reservoir, São Paulo State, Brazil. Hydrobiologia 424:51-65.

CARVALHO, M.C. 2003. Comunidade fitoplanctônica como instrumento de biomonitoramento de reservatórios do Estado de São Paulo. Tese de Doutorado, Universidade de São Paulo, São Paulo.

CHORUS, I. \& BARTRAM, J. 1999. Toxic cyanobacteria in water - A guide to their public health consequences, monitoring and management. E \& FN Spon, New York.

CETESB. 1998. Relatório de qualidade de águas interiores do Estado de São Paulo, 1997. Companhia de Tecnologia de Saneamento Ambiental, São Paulo.

CETESB. 2003. Relatório de qualidade das águas interiores do Estado de São Paulo. Companhia de Tecnologia de Saneamento Ambiental, São Paulo.

COSTA, S.M. \& AZEVEDO, S.M.F.O. 1994. Implantação de um banco de culturas cianofíceas tóxicas. Iheringia 45:6974.

DIEHNELT, C.W., PETERMAN, S.M. \& BUDDE, W.L. 2005. Liquid chromatography-tandem mass spectrometry and accurate $\mathrm{m} / \mathrm{z}$ measurements of cyclic peptide cyanobacteria toxins. Trends in Analytical Chemistry 24:622-634. 
HARADA, K.-I. 1996. Trace analysis of microcystins. Phycologia 35:36-41.

HARADA, K.-I., SUZUKI, M., DAHLEM, A.M., BEASLEY, V.R., CARMICHAEL, W.W. \& RINEHART, K.L. 1988a. Improved method for purification of toxic peptides produced by cyanobacteria. Toxicon 26: 433-439.

HARADA, K.-I., MATSUURA, K., SUZUKI, M., OKA, H., WATANABE, M.F., OISHI, S., DAHLEM, A.M., BEASLEY, V.R. \& CARMICHAEL, W.W. 1988b. Analysis and purification of toxic peptides from cyanobacteria by reversed-phase high-performance liquid chromatography. Journal of Chromatography 448:275-283.

KOMÁREK, J. \& ANAGNOSTIDIS, K. 1989. Modern approach to the classification system of cyanophytes, 4: Nostocales. Algological Studies 56:247-345.

KOMÁREK, J. \& ANAGNOSTIDIS, K. 1999. Cyanoprokaryota. 1. Chroococcales. In Süsswasserflora von mitteleuropa (H. Ettl, G. Gärtner, H. Heynig \& D. Mollenhauer, eds.). Gustav Fischer, Jena, v.19, p.1-545.

LINGEMAN, H. \& TJANDEM, U.R. 1990. Sample pretreatment procedures. In Detection-oriented derivatization techniques in liquid chromatography (H. Lingeman \& W.J.M. Underberg, eds.). Marcel Denker, New York, p.85-151.

MERILUOTO, J. 1997. Chromatography of microcystins. Analytica Chimica Acta 352:277-298.

OJANPERÄ, I., PELANDER, A., VUORI, E., HIMBERG, K., WARIS, M. \& NIINIVAARA, K. 1995. Detection of cyanobacterial hepatotoxins by TLC. Journal of Planar Chromatography 8:69-72.

PELANDER, A., OJANPERÄ, I., SIVONEM, K., HIMBERG, K., WARIS, M., NIINIVAARA, K. \& VUORI, E. 1996. Screening for cyanobacterial toxins in bloom and strain samples by thin-layer chromatography. Water Research 30:1464-1470.

PELANDER, A., SIVONEM, K., OJANPERÄ, I. \& VUORELA, H. 1997. Retardation behavior of cyanobacterial hepatotoxins in the irregular part of the "Prisma" model for thin layer chromatography. Journal of Planar Chromatography 10:434-440.

PELANDER, A., OJANPERÄ, I. \& VUORI, E. 1998. Analysis of cyanobacterial hepatotoxins by overpressured layer chromatography. Journal of Planar Chromatography 11:365-369.

PELANDER, A., OJANPERÄ, I., LAHTI, K., NIINIVAARA, K. \& VUORI, E. 2000. Visual detection of cyanobacterial hepatotoxins by thin-layer chromatography and application to water analysis. Water Research 34:2643-2652.
PIETRZY, D.I. 1989. Organic polymeric stationary phases. In High performance liquid chromatography (P.R. Brown \& R.A Hartwick, eds.). Wiley-Interscience Publication, New York, p.223-276.

POON, G.K., PRIESTLEY, I.M., HUNT, S.M., FAWELL, J.K. \& CODD, G.A. 1987. Purification procedure for peptide toxins from the cyanobacterium Microcystis aeruginosa involving high-performance thin-layer chromatography. Journal of Chromatography 387:551-555.

RAMANAN, S., TANG, J. \& VELAYUDHAN, A. 2000. Isolation and preperative isolation of microcystins variants. Journal of Chromatography 883:103-112.

RAPALA, J., ERKOMAA, K., KUKKONEN, J., SIVONEM, K. \& LAHTI, K. 2002. Detection of microcystins with protein phosphatase inhibition assay, high-performance liquid chromatography-UV detection and enzyme-linked immunosorbent assay. Comparison of methods. Analytica Chimica Acta 466:213-231.

SANT'ANNA, C.L. \& AZEVEDO, M.T.P. 2000. Contribution to the knowledge of potentially toxic Cyanobacteria from Brazil. Nova Hedwigia 71:359-385.

SENDACZ, S. \& KUBO, E. 1999. Zooplâncton de reservatórios do Alto Tietê, Estado de São Paulo. In Ecologia de reservatórios: estrutura, função e aspectos sociais. São Paulo (R. Henry, ed.). Fapesp, São Paulo, p.509-530.

SOUZA, R.C.R., CARVALHO, M.C. \& TRUZZI, A.C. 1998. Cylindrospermopsis raciborskii (Woloszynska) Seenayya \& Subba Raju (Cyanobacteria) dominance and a contribution to the knowledge of Rio Pequeno Arm, Billings Reservoir, Brazil. Environmental Ecology and Water Quality 13:73-81.

SPOOF,L., VESTERKVIST,P.,LINDHOLM,T. \& MERILUOTO, J. 2003. Screening for cyanobacterial hepatotoxins, microcystins and nodularin in environmental water samples by reversed-phase liquid chromatographyelectrospray ionisation mass spectrosmetry. Journal of Chromatography A 1020:105-119.

TSUJI, K., NAITO, S., KONDO, F., WATANABE, M.F., SUZUKI, S., NAKAZAWA, H., SUZUKI, M., SHIMADA, T. \& HARADA, K.-I. 1994. A clean-up method for analysis of trace amounts of microcystins in lake water. Toxicon 32:1251-1259.

XAVIER, M.B. 1981. Represa Billings, São Paulo. I: Fitoplâncton e características físicas da água. Boletim do Instituto de Pesca 8:23-46.

ZAGATTO, P.A., ARAGÃO, M.A., DOMINGUES, D.F., BURATINI, S.V. \& ARAÚJO, R.P.A. 1996. Avaliação ecotoxicológica do reservatório de Guarapiranga, SP, com ênfase à problemática das algas tóxicas e algicidas. Anais do IV Congresso Latino-americano, II Reunião Ibero-americana, VII Reunião Brasileira de Ficologia. Sociedade Brasileira de Ficologia, São Paulo, p.63-81. 